Bangladesh J. Plant Taxon. 27(2): 447-451, 2020 (December)

(C) 2020 Bangladesh Association of Plant Taxonomists

\title{
LICHEN FLORA OF NATIONAL BOTANICAL GARDEN, MIRPUR, DHAKA
}

\author{
Abdullah-Al-Kaium ${ }^{1}$ and Shamim Shamsi* \\ Department of Botany, University of Dhaka, Dhaka 1000, Bangladesh.
}

Keywords: Lichen flora;Six genera; National Botanical Garden; Bangladesh.

An investigation was carried out to study lichen flora of National Botanical Garden, Mirpur, Dhaka during May 2018 to April 2019. Six genera of lichens namely Cladonia, Cryptothecia, Herpothallon, Parmelia, Pertusaria and Usneawere recorded from 15 blocks of the garden. Out of six genera Usnea and Cladonia are new record for Bangladesh. Most frequently occurring lichen genus Parmelia was isolated in pure culture. Anatomical study and chemical tests were done in the Laboratory of Mycology and plant pathology, Department of Botany, University of Dhaka. The present investigation will enrich the knowledge on uses and documentation of lichen flora in Bangladesh.

Lichen is by defination a symbiotic organism. Symbiotic partners are phycobiont (algae) and mycobiont (fungi). Due to over population and industrial revolution, toxicity and pollution increases day by day in Dhaka city. Whereas lichen is an eco-friendly symbiont in nature. National Botanical Garden is a restricted area where indigenous and rare plants are served. In addition, National Botanical Garden is rich in plant resources. So the location was selected to study lichen flora. Considering the above fact, the present investigation has been undertaken with the following objectives: i. Collection of lichen from National Botanical Garden. ii. Identification of respective fungus associated with selected lichen. iii. Isolation of fungus with most frequently occurred lichen and iv. Study of anatomical features of most occurred lichen.

National Botanical Garden is divided into 57 sections and is managed by Forest Department under Ministry of Environment and Forests, Government of Bangladesh. Lichen were collected from 15 blocks among 57 blocks. Twenty four observations were made with the interval of 15 days. Collection of Lichen was followed by May (2000). D3200 Nikon DSLR camera was used for spot photography; Euro sCMEX scientific camera and Nikon Optiphot-2 compound trinocular microscope were used to shoot anatomical features and mycobiont structure. Morphological identification was done according to McFarlin and Melinda (1991); Albert (1998) and Thomas (2008).

Components of a lichen react with certain test chemicals to give color reactions which assist in the identification of a species. Chemical identification of collected lichen samples have been done according to the method described by Orange et al. (2001). Anatomy of Parmelia carried out by following Richardson (1960). Fungi associated with the lichen were isolated separately following Tissue planting method (CAB 1968).

Six genera of lichen were recorded in National Botanical Garden Mirpur, Dhaka. They are Cladonia, Cryptothecia, Herpothallon, Parmelia, Pertusuria and Usnea. Among the 57 blocks lichen were recorded from 15 blocks of the garden. Identification was done by both morphological and chemical test.

*Corresponding author, E-mail: prof.shamsi@gmail.com

${ }^{1} \mathrm{~A}$ part of MS thesis of first author. 
1. Cladonia sp. P. Browne L.1.I.ID*: 1624-14425

(Fig. 1A)

Kingdom-Fungi, Division- Ascomycota, Class- Lecanoromycetes, Order- Lecanorales, Family- Cladoniaceae. Thallus squamulose, fruticose, shrub-like, beard-like. Upper surface bluish green. Thallus smooth, plane. Lower surface whitish. Hyaline or colorless pigmentation observed. Spot tests and chemistry- K,C, KC and Logul's solution showed positive result.

Specimen examined: Recorded on Artocarpus heterophyllus (Jackfruit), from Block 39 of National Botanical Garden, Mirpur Dhaka, A.A. Kaium 08, 01 August 2018.

2. Cryptothecia sp. Stirt. 1876L.1.I.ID*:1795- 13699

(Fig. 1B)

Kingdom- Fungi, Division- Ascomycota, Class- Arthoniomycetes, Order- Arthoniales, FamilyArthoniaceae. The body of the lichen forms continuous, circular crust-like patches on dead wood, readily recognizable by the prominent red pigment. It is a crustose lichen, because it grows in the form of a surface crust. Central region is covered with red, spherical to cylindrical granules. Moving outwards from the center, zones of color was distinguished, the first gray-green, the second white, and finally a bright red cottony rim. It is $0.15-0.30 \mathrm{~mm}$ thick, and can be smooth, or have low radiating ridges.Spot tests and chemistry- K,C, KC and Logul's solution showed positive result.

Specimen examined: Recorded on Mangifera indica L. (Mango tree) from Block 13 of National Botanical Garden, Mirpur Dhaka,A.A. Kaium 16, 15 December 2018.

3. Herpothallon sp. Aptroot, Lücking \& G. Thor, 2009L.1.I.ID*:14608- 15358

(Fig. 1C) Kingdom- Fungi, Division- Ascomycota, Class- Arthoniomycetes, Order- Arthoniales, FamilyArthoniaceae. Thallus corticolous, delimited by a compact brown prothallus; thallus surface greyish to greenish white to cottony, in the centre densely covered by pale beige to grayish white. Marginal and upper surface present. Upper surface rugulose, finely wrinkled. Spot tests and chemistry- K,C, KC and Logul's solution showed positive result.

Specimen examined: Recorded on Artocarpus heterophyllus (Jackfruit) from Block 9 of National Botanical Garden, Mirpur Dhaka,A.A. Kaium 22, 01 March 2018.

4. Parmelia sp. (L.) Ach. (1803) L.1.I.ID*: 8604- 9818

(Fig. 1D)

Kingdom- Fungi, Division- Ascomycota, Class- Lecanoromycetes, Order- Lecanorales, FamilyParmeliaceae. The thallus of the Parmeliais foliose, large, distinctly branched and lobed.The colors varied from gray to brown mixed with green and bluish-green to brown dark. It was foundon trees, fences and roof of old building. Some acquire considerable dimensions, reaching three to four inch in diameter. There is continued marginal growth while the central portion dies away. Spot tests and chemistry- K,C, KC and Logul's solution showed positive result.

Specimen examined: Recorded on Polyalthia longifolia (Debdaru) from Block 3of National Botanical Garden, Mirpur Dhaka, A.A. Kaium 12, 15 September 2018.

5. Pertusaria sp. DC. (1805).L.1.I.ID*: 8311- 8433

(Fig. 1E)

Kingdom- Fungi, Division- Ascomycota, Class- Lecanoromycetes, Order- Pertusariales, FamilyPertusariaceae. It was found on bark. Thallus is crustose type. Upper surface gray-white.It became more green during rainy season. Thallus was about $2-3 \mathrm{~cm}$ diameter. Spot tests and chemistry- $\mathrm{K}$ ,C, KC and Logul's solution showed positive result.

Specimen examined: Recorded on Artocarpus heterophyllus (Jackfruit) from Block 51 of National Botanical Garden, Mirpur Dhaka,A.A. Kaium 22, 01 March 2018. 

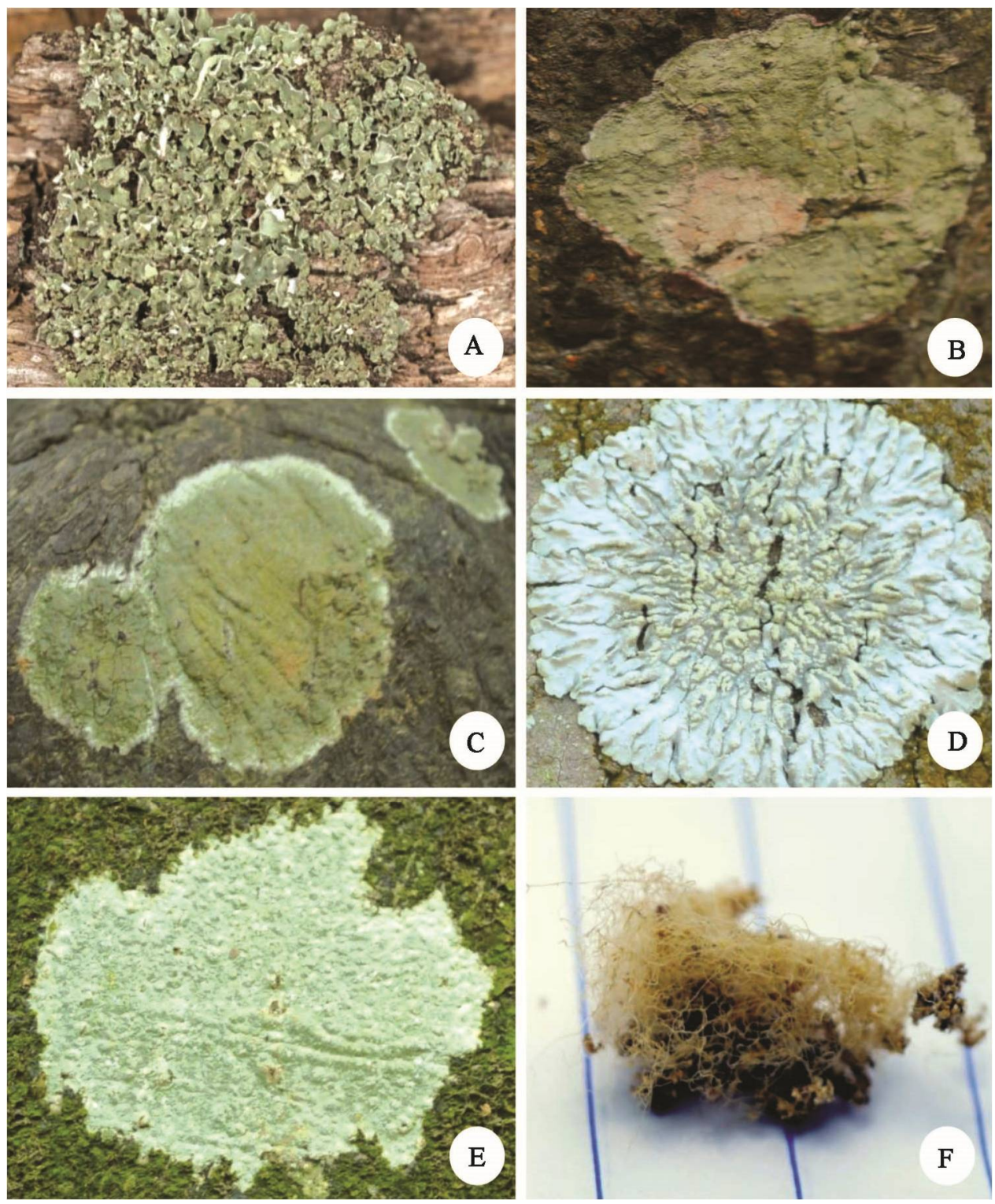

Fig. 1.Photograph of lichen thallus: A. Cladonia sp. B Cryptothecia sp, C. Herpothallon sp. D. Parmelia sp. E. Pertusaria sp F. Usnea sp.

D. Parmelia, E. Pertusaria and F. Usnea

6. Usnea sp.Dill. ex. Adans. (1763)L.1.I.ID* 6615-9282.

(Fig.1F)

Kingdom- Fungi, Division- Ascomycota, Class- Lecanoromycetes, Order- Lecanorales, Family- Parmeliaceae. Fruticose lichens grown like leafless mini-shrubs or tassels anchored on bark. Thallus continues and diffusive. Upper surface grayish green. Marginal upper surface absent.Thallus structure ranges between $0.5-1.0 \mathrm{~cm}$. Colorless and hyaline pigmentation observed on the thallus.Spot tests and chemistry- K,C, KC and Logul's solution showed positive result. 
Specimen examined: Recorded from Block No. 51 of National Botanical Garden, Mirpur Dhaka,A.A. Kaium 07, 15 May 2018.

*L 1 I ID (Lias Light Item Description) www.liaslight.lias.net. A Lichen Database.

Parmelia sp. (L.)Ach. (1803)

(Fig. 2)

Colony whitish, reverse brownish.Thallus quite large, outside part of the colony is dichotomously branched. Upper surface usually smooth, sometimes bearing brownish to whitish. Lower surface brown to black.Spores typical, $5 \mu \mathrm{m}-13 \mu \mathrm{m}$ diameter.

Specimen examined: Isolate of Parmelia lichen, collected from National Botanical Garden, Mirpur, Dhaka. A.A. Kaium 05,15 May 2018.
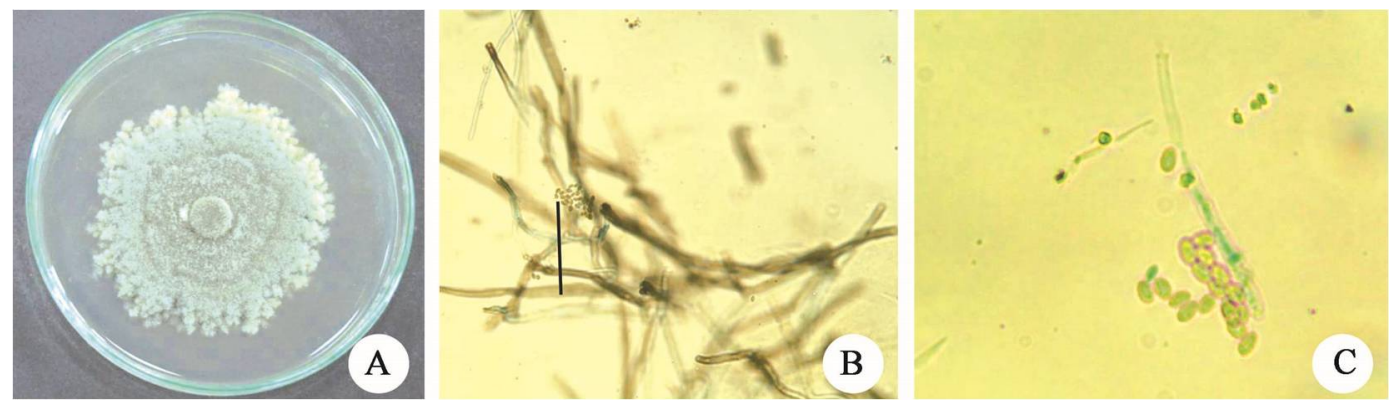

Fig.2A. Parmelia sp: A. Colony on PDA plate, B. Mycelial growth and C. Spores. (Bar= $50 \mu \mathrm{m})$.

Parmelia thallus was taken to study anatomical features of the lichen. Lichen thallus were compared with a typical leaf Parmelia has a wide thallus that actually bearing photobiont and mycobiont. area follows: Upper cortical layer- This consists of a compact tissue of short-celled hyphae. It forms a protective layer for the tissues beneath. The upper portion of this layer is colored, due to a deposit of acid crystals. The function of this colored substance is twofold. The layer was not uniform in thickness. It allowed the algae to approach nearer the surface for the purposes of greater chlorophyllin activity. Algal Layer-This lies beneath the upper cortical layer, and consisted of a loose network of hypha. In which the algae are suspended. It is the layer in which carbon assimilation is carried on. Certain hyphal branches, the haustoria, enclose and even penetrate the algae. Medullary Layer-This consisted of a very loosened of hyphae. It contains air. The thickness of this layer varies considerably. Lower Cortical Layer- When resembles the upper cortical layer, usually it is deficient. From the lower surface, whether cortical or not, the rhizoids extend. These are hyphae, either single or in groups, which grow vertically downward into the substratum. The rhizoids are colored black. The cilia at the mars fin of many foliose thalli were morphologically and functionally analogous to aerial rhizoids. The Apothecia-The apothecia were the spore-bearing structures developed in or upon the thallus. They were structurally very similar to the spore producing organs of fungi (Ascomycetes, sac-fungi). the apothecia were cup like remained within their interior algae, thus acting as assimilating organs. In others, particularly the lower forms, the apothecia retain the structural characters of their fungal ancestors, that is, they do not bear algae, and hence do not take part in the function of assimilation. Upon the presence or absence of algae are based the distinctions into fungal and thaliana apothecia. This differs from the foregoing in that the algal layer of the thallus extends into the apothecium, usually forming two layers; one immediately underneath the hypothecium, and the other just above the lower cortical layer of the apothecium. The algae approached quite to the margin of the cup, or they extended 
only a part way up. In fact, there are all gradations, from the purely fungal type to the most highly developed thallus type as it occurs in the Parmelia (Figs 2-3).

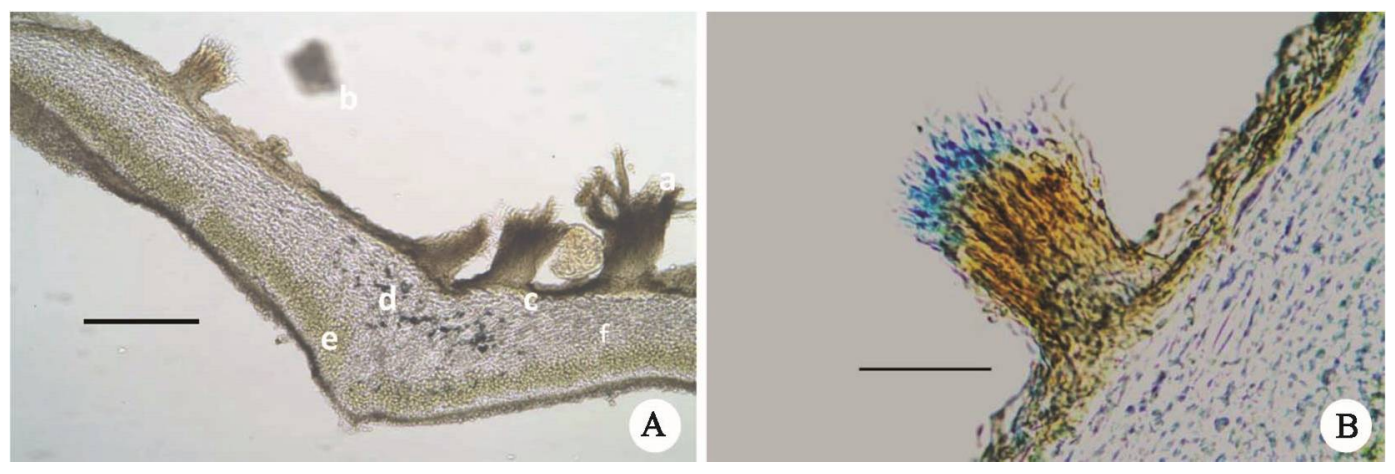

Fig. 3.T.S. of Parmelia sp. thallus: a. Apothecia, b. Dispersal fragment, c. Cortex (Outer layer), d. Medulla, e. Photobiont, f.Lower Cortex. B. Apothecium of Parmelia sp. mounted with cotton blue. (Bar = 50 $\mu \mathrm{m}$.

Authors extensively studied lichen flora of Bangladesh. Alam and Gafur (2008) reported twelve taxa under twogenera of lichens from Sal forest in Gazipur. Aptroot and Hossain (2011) observed fifty one pantropica llichen from Bangladesh. A detailed survey of literature revealed the genera Usnea and Cladonia has not been reported so far in any relevant literature of Bangladesh.

\section{Acknowledgement}

The first author (AAK) gratefully acknowledges the financial support by the Ministry of Science and Technology, Government of the People's Republic of Bangladesh through NST fellowship.

\section{References}

CAB (Commonwealth Agricultural Bureau) 1968. Plant Pathologist's Pocket Book. $1^{\text {st }}$ edn. The Commonwealth Mycological Institute, England. 267 pp.

Alam, N. and Gafur, M.A. 2008. Lichen flora in Chandra sal forest: occurrence, distribution and abundance. Bangladesh J Bot. 37(1): 61-65.

Albert, S.1998. A Guide to the Study of Lichens.California State College. $2^{\text {nd }}$. edn.pp.302.

Aptroot, A. and Hussain, I.S. 2011. Some lichens of Bangladesh. The Bryologist. 114: 466-468. $10.2307 / 41289804$.

Friedmann, E.I. 1991. Endolithic microorganisms in the Antarctic cold desert. Science, 215:1045-1053.

MayPF. 2000. How to collect lichens. Farlow Herbarium, Harvard University, Cambridge, Massachusetts. pp. 453.

Mc Farlin and Melinda 1991 A morphological and chemical study of the lichen Genus Hypogymnia in North America North of Mexico". Honors Projects. Paper 29.

Orange, A., James, P.W. and White, F.J. 2001.Micro-chemical Methods for the Identification of Lichens. British Lichen Society, London. 23: 231-235

Thomas HN 2008. Lichen Biology. Cambridge University Press. $2^{\text {nd }}$ edn. pp. 489. 